\title{
PROMOTING INCLUSION THROUGH EXCLUSION: HIGHER EDUCATION's ASSAULT ON THE FIRST AMENDMENT
}

\author{
Adam Lamparello* \\ "Free speech and a constructive climate for learning are not incompati- \\ ble."1
}

\section{INTRODUCTION}

Higher education is becoming the modern day Gestapo.

Most would agree that faculty members at universities across the country should not be permitted to make racial, prejudicial, stereotypical, and highly offensive comments in the classroom toward individual students or groups. The difficult question is delineating the line between unpopular speech that offends members of the student and academic community, and unpopular speech that, while offensive, must be tolerated as part of classroom and university discourse. ${ }^{2}$

* Associate Dean and Assistant Professor of Law, Indiana Tech Law School.

1 Eric Owens, Washington State U. SMACKS DOWN Professors Who Want to CENSOR Politically-Incorrect Language, THE DAILY CALLER (Sept. 1, 2015), http://dailycaller.com/2015/09/01/washington-state-u-smacks-down-professors-who-want-tocensor-politically-incorrect-language/; see also Justin Wm. Moyer, Washington State University Class Bans 'Offensive’ Terms Like Male, Female, Tranny, Illegal Alien, Wash. Post Sept. 2, 2015, http://tablet.washingtonpost.com/rweb/politics/college-class-bans-offensive-terms-likemale-female-tranny-illegal-alien/2015/09/02/1ae482a4257a6736a9dcb8b6f3a77875_story.html (expanding more on the details of the speech policy).

2 The American Association of University Professors' Statement on Academic Freedom, as well as many university policies governing free speech, are riddled with ambiguities that fail to guide administrators, faculty, and students. The AAUP statement on academic freedom provides as follows:

Teachers are entitled to full freedom in research and in the publication of the results, subject to the adequate performance of their other academic duties. . . . Teachers are entitled to freedom in the classroom in discussing their subject, but they should be careful not to introduce into their teaching controversial matter which has no relation to their subject. ... College and university teachers are citizens, members of a learned profession, and officers of an educational institution. When they speak or write as citizens, they should be free from institutional censorship or discipline, but their special position in the community imposes special obligations. As scholars and educational officers, they should remember that the public may judge their profession and their institution by their utterances. Hence they should at all times be accurate, should exercise appropriate restraint, should show respect for the opinions of others, and should make every effort to indicate that they are not speaking for the institution. AMERICAN ASSOCIATION OF UNIVERSITY 
This essay argues that universities have gone too far in suppressing unpopular, even distasteful, speech that is accorded the highest degree of First Amendment protection and that is vital to facilitating the robust exchange of ideas and viewpoints among students and faculty. As discussed below, university administrators have censored faculty members and, in some cases, adopted policies that discourage core political speech, discriminate against speech on the basis of its content, and deter faculty and students from expressing controversial views.

In so doing, many universities have manufactured artificial utopias based on a philosophy of avoiding, not confronting, unpopular ideas, and of pacifying, not empowering, students in the pursuit of knowledge. In this way, some universities have become equivalent to the anxiety-riddled parent who shelters a child from the evils of the world, only to find out years later that the child is woefully unprepared for life's challenges. The same result occurs when universities pamper, coddle, and over-react to the whims of every hyper-sensitive student who would rather label a professor or fellow student "insensitive" than engage in a constructive dialogue with students and faculty who have different opinions. Students are unprepared for the world they are about to enter, and the educational benefits of a diverse student body are compromised, if not entirely abandoned. Put differently, the fact that universities are "educating the young for citizenship is reason for scrupulous protection of Constitutional freedoms of the individual, if we are not to strangle the free mind at its source and teach youth to discount important principles of our government as mere platitudes."3

Nowhere are free speech rights more important than in higher education. As the Supreme Court has recognized, "classroom discussion is livelier, more spirited, and simply more enlightening and interesting" when students have "the greatest possible variety of backgrounds," knowledge is acquired through "speculation, experiment and creation." In Keyishian v. Board of Regents, ${ }^{6}$ the United States Supreme Court held as follows:

Our Nation is deeply committed to safeguarding academic freedom, which is of transcendent value to all of us and not merely to the teachers concerned. That freedom is therefore a special concern of the First Amendment, which does not

ProfeSSORS, 1940 Statement of Principles on Academic Freedom and Tenure available $a t$ : http://www.aaup.org/report/1940-statement-principles-academic-freedom-and-tenure.

These and other policies provide minimal, if any, guidance to university personnel, and make it likely that policies concerning free speech will be largely subjective and, in some case, motivated by discrimination against particular viewpoints.

3 Bd. of Educ., Island Trees Union Free Sch. Dist. No. 26 v. Pico, 457 U.S. 853, 864-65 (1982) (quoting West Virginia State Board of Educ. v. Barnette, 319 U.S. 624, 637 (1943)).

4 Grutter v. Bollinger, 539 U.S. 306, 330 (2003).

5 Regents of the Univ. of Cal. v. Bakke, 438 U.S. 265, 312 (1978) (quoting Sweezy v. New Hampshire, 354 U.S. 234, 263 (1957)).

6385 U.S. 589 (1967). 
tolerate laws that cast a pall of orthodoxy over the classroom. The vigilant protection of constitutional freedoms is nowhere more vital than in the community of American schools. ${ }^{7}$

When Universities over-regulate classroom speech by professors and students, they engage in precisely what the First Amendment seeks to prevent, and prohibit precisely what the First Amendment seeks to foster: a heterogeneous classroom environment in which students of all backgrounds can express opinions without the fear of reprisal, without the threat of censure, and without the "pall of orthodoxy" that renders free speech an abstract, rather than concrete, right. $^{8}$

The problem with the Supreme Court's jurisprudence, and university policies governing free speech, is the exclusive focus on whether the faculty member's speech warrants first amendment protection, and not on whether a faculty member or student can actually prove that particular speech or expressive conduct, even if protected, resulted in cognizable legal harm. This essay proposes a framework for evaluating the free speech rights in higher education that is analogous, in part, to two prongs under the standard for adjudicating sexual harassment jurisprudence under Title VII of the Civil Rights Act. Under Title VII, employees are entitled to a workplace that is free of "discriminatory intimidation, ridicule, [and] insult," and may recover for sexual harassment where the employee was a member of protected class, subject to unwanted sexual harassment based on sex that "affected a term, condition, or privilege of employment," 10 and where the employer failed to take remedial measures. ${ }^{11}$ By way of analogy, faculty members and students should likewise be entitled to an educational environment that is free of discrimination, coercion and intimidation, but the law (and university policies) should only provide a remedy where the speech: (1) is subjectively and objectively unwelcome; (2) is offensive to an individual of reasonable sensibilities; and (3) creates a hostile educational environment that is not conducive to the expression of different views. ${ }^{12}$ In conducting this analysis, courts should consider, among other things, the following factors:

The context in which the speech was made, including its pedagogical value and relevance to the subject matter or course;

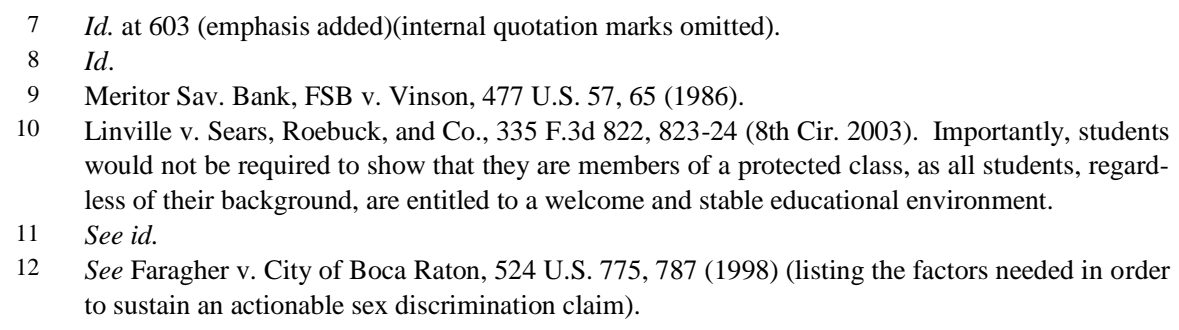


Whether the speech "unreasonably interferes with a [student's] work performance,"13 which entails a focus on whether a reasonable person of ordinary sensibilities would find the speech offensive and unwelcome; and

Whether the speech was targeted at specific students or groups.

Of course, given the fact that students often do not have the means or desire to file legal actions against their universities, this standard would be less stringent that that governing Title VII claims. In addition, it would not prevent universities from enforcing "reasonable time, place, and manner regulations"14 on certain types of speech. In doing so, this standard would strike a more appropriate chord than many current university policies, which err on the side of suppressing, rather than encouraging, protected speech. Indeed, students and faculty members should not be allowed to complain about speech that, although personally offensive or distasteful, would not be offensive to the reasonable person. ${ }^{15}$ Furthermore, although a university has a duty to protect students from offensive speech that has minimal pedagogical educational value, speech policies should not become a "general civility code,"16 or promote an educational climate that is based largely on the speculative harms that might result from controversial speech or, worse, disagreement with a speaker's viewpoint. Such an approach would undermine, rather than encourage, the free flow of ideas, and make the classroom more, not less, divorced from the real world.

Part II discusses troubling developments in higher education that have led to the over-policing of speech, and over-reaction to students claiming to be "offended" by a faculty member's speech inside the classroom. Part III argues that courts and universities should adopt a new framework for evaluating analogous to Title VII sex discrimination claims when inquiring whether a faculty member's speech warrants legal protection. Ultimately, "the comprehensive authority ... of school officials" must be exercised "consistent with fundamental constitutional safeguards," require universities to embrace, not shun, all viewpoints, and to encourage, not eradicate, speech with which some, or even most, may disagree.

13 Id. at 787-88

14 Widmar v. Vincent, 454 U.S. 263, 276 (1981).

15 Of course, there will be instances in which speech that would not be grounds for a cognizable claim under this standard would still be considered offensive to a reasonable person. For example, a statement to an Asian person that "You must be good at math," could certainly be viewed as offensive and should be discouraged, but it should not be the basis upon which to fire faculty members or label someone "racist." See, e.g., Hazelwood Sch. Dist. v. Kuhlmeier, 484 U.S. 260, 273 (1988) (school officials may restrict some speech on the basis of content if it is "reasonably related to legitimate pedagogical concerns"). A standard analogous to that used in Title VII sex discrimination claims can provide a baseline by which university administrators can address free speech issues and respond proportionately and fairly to complaints.

16 Faragher, 524 U.S. at 788 (internal quotation omitted).

17 Tinker v. Des Moines School Dist., 393 U.S. 503, 507 (1969). 


\section{INCLUSION THROUGH EXCLUSION: UNDERMINING THE FIRST AMENDMENT AND THWARTING THE FREE EXCHANGE OF IDEAS}

The purpose of obtaining a college or graduate degree is not merely to acquire knowledge. Students must learn to apply that knowledge to realworld situations and interact with people of diverse backgrounds and beliefs. The over-regulation of speech is entirely inconsistent with this objective.

\section{A. The Core Purpose of Higher Education}

Higher education provides students with to the opportunity to collectively discover truth "out of a multitude of tongues, [rather] than through any kind of authoritative selection," 18 and connects classroom discourse to the diverse perspectives students will encounter in the real world. One commentator states as follows:

Attempts to shield students from words, ideas, and people that might cause them emotional discomfort are bad for the students. They are bad for the workplace, which will be mired in unending litigation if student expectations of safety are carried forward. And they are bad for American democracy, which is already paralyzed by worsening partisanship. When the ideas, values, and speech of the other side are seen not just as wrong but as willfully aggressive toward innocent victims, it is hard to imagine the kind of mutual respect, negotiation, and compromise that are needed to make politics a positive-sum game. Rather than trying to protect students from words and ideas that they will inevitably encounter, colleges should do all they can to equip students to thrive in a world full of words and ideas that they cannot control. One of the great truths taught by Buddhism (and Stoicism, Hinduism, and many other traditions) is that you can never achieve happiness by making the world conform to your desires. But you can master your desires and habits of thought. This, of course, is the goal of cognitive behavioral therapy. With this in mind, here are some steps that might help reverse the tide of bad thinking on campus. ${ }^{19}$

In Regents of University of California v. Bakke, ${ }^{20}$ the Court noted that "law school, the proving ground for legal learning and practice, cannot be effective in isolation from the individuals and institutions with which the law interacts," and "removed from the interplay of ideas and the exchange of views with which the law is concerned." 21 Concerning medical school, the Court noted that "[p]hysicians serve a heterogeneous population," and "[a]n otherwise qualified medical student with a particular background-

18 Bakke, 438 U.S. at 312 (quoting United States v. Associated Press, 52 F. Supp. 362, 372 (S.D.N.Y. 1943)).

19 Greg Lukianoff \& Jonathan Haidt, The Coddling of the American Mind, ThE ATLANTIC, Sept. 2015, available at http://www.theatlantic.com/magazine/archive/2015/09/the-coddling-of-theamerican-mind/399356/.

20438 U.S. 265 (1978).

21 Id. at 314 (internal citation omitted). 
whether it be ethnic, geographic, culturally advantaged or disadvantagedmay bring ... ideas that enrich the training of its student body and better equip its graduates to render with understanding their vital service to humanity." 22 Simply put, if the inclusion of controversial topics and exchange of controversial beliefs is prohibited, no university can make the claim that it is inclusive.

In recent years, however, Universities have adopted policies that result in the suppression of speech on matters of political and social importance, and that reflect the diversity of the classroom environment. The stated reason for such policies - to foster an inclusive educational environment and eliminate intolerant, divisive, and offensive speech - is the height of hypocrisy. These policies discourage faculty members from expressing unpopular views, inhibit rigorous classroom discussion on matters of social importance, and over-react to the hyper-sensitivities of students who would rather avoid, than confront, topics and opinions they find distasteful. In so doing, universities are achieving an artificial atmosphere of "inclusion" through exclusion, undermining free speech values, and undercutting the education values of diversity.

\section{B. Over-Sensitizing the Academic Environment: Misguided Attempts to Suppress Speech}

\section{Discouraging "Microaggressions"}

Microagressions, which are facially innocuous statements that purportedly contain insensitive underlying messages, are the newest rave in higher education's mission to pacify even the most sensitive minds. For example, the University of California at Berkeley recently issued a memorandum to professors discouraging the used of what it calls "microagrressions." For example, Berkeley has discouraged faculty from making statements such as:

"Men and women have equal opportunities for achievement."

"I believe the most qualified person should get the job."

"America is a melting pot."

"Why are you so quiet?"23

23 Recognizing Microagressions and the Messages They Send, available at http://www.ucop.edu/academic-personnel-

programs/_files/seminars/Tool_Recognizing_Microaggressions.pdf; see also Robby Soave, The University of California's Insane Speech Police, THE DAILY BEAST, June 22, 2015, available at http://www.thedailybeast.com/articles/2015/06/22/the-university-of-california-s-insane-speechpolice.html (reporting on the adverse effects that the UC Berkeley memorandum might have on free speech). 
Admittedly, some speech that technically classifies as a "microagression" is insensitive and has questionable pedagogical value. The phrase "You are a credit to your race," can be understood by a reasonable person to imply that the speaker views that race as inferior. Statements like these have no pedagogical value and should be actively discouraged in the educational setting. Conversely, a statement such as "I think the most qualified person should get the job" may reflect a merit-based philosophy and possibly opposition to affirmative action, but it certainly does not suggest animus or prejudice toward a racial or ethnic group. If anything, this statement suggests that the speaker does not support the use of affirmative action in higher education. This may spark vehement disagreement, but it certainly does not convey intolerance or create a hostile educational environment. When universities target this speech, regardless of their good intentions, the fear of reprisal for voicing such opinions is likely to have a chilling effect on free speech.

\section{Bans on Politically-Incorrect Speech by Faculty and Students}

Some faculty members at Washington State University recently banned students from using words like "[c]olored people," and "[t]ranny" in the classroom, on the grounds that these words can be offensive to many students [and] create an uncomfortable, if not hostile, classroom environment, and respective dialogue. ${ }^{24}$

Furthermore, one professor at Washington State warned white students that, "to do well in this class" 25 and to reflect their "grasp of history and social relations" white students should defer "to the experiences of people of color." 26 Yet another professor teaching a feminism course at Washington State stated in her syllabus that students risked "failure for the semester" 27 if they referred to men and women by the term "male" or "female." 28 Fortunately, Washington State University's President intervened to warn faculty that such conduct was not consistent with fostering "[o]pen dialogue, vigorous debate and the free exchange of ideas, as well as the language

24 College Class Bans "Offensive" Words, THE J. GAZETTE (September 3, 2015), http://www.journalgazette.net/news/us/College-class-bans-offensive-words-8574432. (brackets added).

25 Eric Owens, Washington State U. Smacks Down Professors Who Want to Censor PoliticallyIncorrect Language, DAILY CALLER (Sept. 1, 2015), http://dailycaller.com/2015/09/01/washington-state-u-smacks-down-professors-who-want-tocensor-politically-incorrect-language/.

$26 I d$.

27 Id.

$28 \quad I d$. 
used to convey these ideas," ${ }^{29}$ all of which "are at the core of who we are as a higher education institution." ${ }^{30}$

Of course some of the above statements are undoubtedly offensive. However, a blanket ban on statements that would typically be regarded as offensive ignores the fact that some offensive statements have pedagogical value and therefore will not create an unwelcome and hostile classroom environment. When faced with complaints about such speech, universities should consider the purpose for which these words were uttered, such as where a faculty member or student is quoting from a book or recalling a traumatic incident, and assess their relevance to the course's subject matter.

\section{Bans on "Divisive" Speech}

Moreover, some universities actively ban speech that strives to spark public debate on matters of public interest. The University of Iowa recently removed a seven-foot statute depicting a Ku Klux Klan robe covered with articles concerning racial tensions over the last century. ${ }^{31}$ The artwork was intended to remind students of the horrors of racism, and to encourage progressive dialogue on race relations. ${ }^{32}$ Notwithstanding, the University of Iowa's President branded the artist a racist, and made the following statement:

The University of Iowa is a diverse community with no tolerance for racism, and the artwork that was briefly displayed on the Pentacrest this morning was deeply offensive to members of our community .... The University of Iowa considers all forms of racism abhorrent and is deeply committed to the principles of inclusion and acceptance. There is no room for divisive, insensitive, and intolerant displays on this campus. ${ }^{33}$

The last sentence highlights everything that is wrong with universities that seek inclusion through the exclusion of speech to which the First Amendment affords the highest protection. Furthermore, the university had the audacity to label the artist a racist, thereby smearing his character and ignoring the purpose of the artwork. In fact, it is the university officials, not the artist, who are the poster children for division, insensitivity, and intolerance.

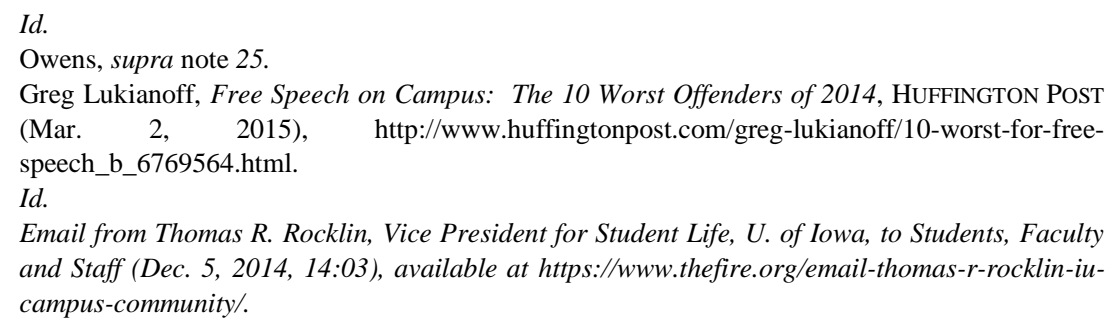

Email from Thomas R. Rocklin, Vice President for Student Life, U. of Iowa, to Students, Faculty and Staff (Dec. 5, 2014, 14:03), available at https://www.thefire.org/email-thomas-r-rocklin-iucampus-community/. 


\section{Bans on Innocuous Speech}

In addition, the University of California-Fullerton flagrantly disregarded First Amendment freedoms when it accused a sorority of engaging in "[d]isorderly, lewd, indecent, or obscene conduct" ${ }^{34}$ for holding an event titled "Taco Tuesday," 35 in which members of the sorority wore sombreros and Mexican clothing. ${ }^{36}$ The university forced the sorority to attend mandatory workshops on "cultural competencies and diversity," 37 even though nothing in the record remotely suggested that the sorority members were motivated by prejudice or intolerance. Similarly, Modesto Junior College administrators prohibited a student from distributing copies of the United States Constitution because the student was not standing within the college's designated "free speech zone," 38 which consists of two relatively small concrete areas on the college's 225 -acre campus. ${ }^{39}$ When a professor at the college voiced support for the student, the college retaliated with a negative job evaluation and restricted his course load. ${ }^{40}$

The obvious problem with banning facially innocuous speech, as well as speech some might consider divisive, is that conclusions regarding the quality and character of the speech are inescapably subjective. Given this fact, universities should adopt policies that focus on the objective reasonableness of the speech, and not discourage or prohibit speech that some students might conceivably find offensive. This approach would recognize that there will be moments in the classroom, as there will be in the real world, where individuals will find speech distasteful. But it is precisely this type of speech that permits students to learn from "the greatest possible variety of backgrounds," experiment and creation." ${ }^{, 2}$

\section{Policies that Inhibit Protected Speech}

Some universities have adopted policies that inhibit the free exchange of ideas, including speech outside of the classroom. The University of Kansas, for example, recently adopted a policy governing the faculty mem-

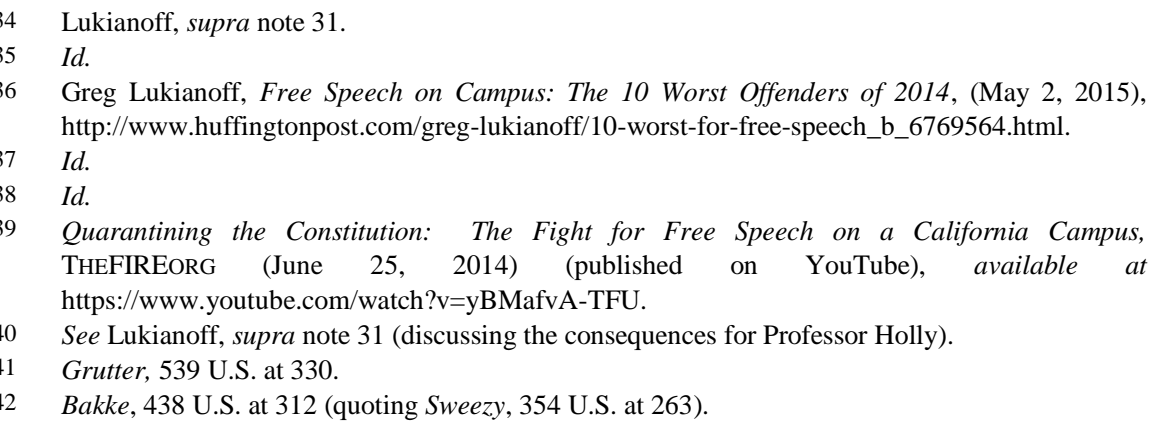


bers' use of social media. The policy contains a paragraph prohibiting the following speech that:

[I]mpairs discipline by superiors or harmony among co-workers, has a detrimental impact on close working relationships for which personal loyalty and confidence are necessary, impedes the performance of the speaker's official duties, interferes with the regular operation of the university, or otherwise adversely affects the university's ability to efficiently provide services. ${ }^{43}$

The policy also provides that "the chief executive officer shall balance the interest of the university in promoting the efficiency of the public services it performs through its employees against the employee's right as a citizen to speak on matters of public concern." 44

\section{Trigger Warnings}

Relatedly, some universities have embraced the use of "trigger warnings," which require professors to advise students in advance of sensitive subject matter that will be discussed in class. ${ }^{45}$ Along with blanket bans on specific words, these policies create an environment in which professors and students must carefully watch their words for fear that the style or content of their utterances might "offend" someone, transgress a university policy, or draw condemnation from faculty colleagues.

Although trigger warnings do not, on their face, appear to threaten free speech rights, the philosophy underlying them is one of avoidance in which students are permitted to opt out of classes where sensitive subjects are taught. One commentator states as follows:

Some students have called for warnings that Chinua Achebe's Things Fall Apart describes racial violence and that F. Scott Fitzgerald's The Great Gatsby portrays misogyny and physical abuse, so that students who have been previously victimized by racism or domestic violence can choose to avoid these works, which they believe might "trigger" a recurrence of past trauma. ${ }^{46}$

Few would question the enduring and irreparable trauma that can result from being victimized by racism and domestic violence. Thus, a trigger warning can be a sensible tool by which to notify students in advance of sensitive or potentially divisive topics. On the other hand, exempting students from specific classes or assignments can inhibit a constructive classroom dialogue about such topics, make it impossible for students from diverse backgrounds to discuss difficult issues openly, and prevent students

43 See Kansas Board of Regents, Proposed Revision to Board Policy, (Dec. 18-19, 2013) (emphasis added), available 
from challenging the conscious or subconscious beliefs that they may harbor. Of course, professors must use discretion in every situation, particularly where a trauma is recent or the student is clearly unable to participate meaningfully in a discussion. In most situations, however, trigger warnings do not empower students. They allow them to retreat into the same false utopia that aggressive regulations of faculty speech create.

\section{A BETTER FRAMEWORK FOR RESOLVING FIRST AMENDMENT DISPUTES IN HIGHER EDUCATION}

Admittedly, First Amendment protections do not apply equally in all contexts. Free speech rights vary depending on the context within which speech is uttered, and in some cases based on the content of the speech. ${ }^{47}$ Students have diminished free speech rights in public high schools to ensure a stable learning environment for all students. Likewise, universities may-and should-regulate offensive, derogatory, prejudicial or distasteful speech that would otherwise be protected by the First Amendment, but that reflects prejudice toward individual students or groups.

In Healy v. James, ${ }^{48}$ the Supreme Court stated:

[T] he precedents of this Court leave no room for the view that, because of the acknowledged need for order, First Amendment protections should apply with less force on college campuses than in the community at large. Quite to the contrary, ' $(t)$ he vigilant protection of constitutional freedoms is nowhere more vital than in the community of American schools.' The college classroom with its surrounding environs is peculiarly the "marketplace of ideas," and we break no new constitutional ground in reaffirming this Nation's dedication to safeguarding academic freedom. ${ }^{49}$

It is disturbing that the wholesale suppression of speech to which the First Amendment affords the highest constitutional protection is happening at places like California-Berkeley, Washington State, the University of Iowa, and the University of California-Fullerton. And these examples are not anomalies. The new norm in higher education is to suppress speech on the basis of its content while labeling faculty members and students "divisive," "insensitive," or "intolerant." That should change now. The Supreme Court's jurisprudence interpreting Title VII of the Civil Rights Act as applied to claims of sexual harassment provides a principled framework for resolving the free speech disputes in higher education, ironically, to focus less on the First Amendment and more on the effect of the speech on the audience. This encompasses an analysis of whether the speech at issue

47 See, e.g., Hazelwood School Dist., 484 U.S. at 274 (noting that schools can regulate some speech on the basis of content if it is "reasonably related to legitimate pedagogical concerns").

48408 U.S. 169, 180-81 (1972) (quoting Shelton v. Tucker, 364 U.S. 479, 487 (1960), Keyishian, 385 U.S. at 603 and Sweezy, 354 U.S. at 249-50 (plurality opinion)).

49 Healy, 408 U.S. at 180-81. 
was: (a) objectively unwelcome; (2) offensive to an individual of ordinary sensibilities; and (3) likely to create a hostile educational environment.

\section{A. Whether the Speech was Objectively Unwelcome}

In the context of sexual harassment claims under Title VII, the Court has held that "not all workplace conduct that may be described as "harassment' is, in fact, sexual harassment." 50 Furthermore, courts have "never held that workplace harassment, even harassment between men and women, is automatically discrimination because of sex merely because the words used have sexual content or connotations." 51 In fact, a "recurring point . . . is that 'simple teasing,' offhand comments, and isolated incidents (unless extremely serious) will not amount to discriminatory changes in the 'terms and conditions of employment." 52 Furthermore, "not all profane or sexual language or conduct will constitute discrimination in the terms and conditions of employment." 53 Rather, the harassment must be "sufficiently severe or pervasive 'to alter the conditions of [the victim's] employment and create an abusive working environment." "54

A similar principle should apply when assessing if speech at issue in the university context is objectively unreasonable. Not all speech that could conceivably be deemed "offensive" should be censored, and not all students who complain about a faculty member's speech should be entitled to a remedy, legal or otherwise. Instead, courts should consider, among other things, the context within which the speech was made, including its pedagogical value and relevance to the subject matter. To illustrate, in Hardy $v$. Jefferson Community College ${ }^{55}$ the words "bitch," "faggot," and "nigger" were used in a lecture discussing language and social constructivism, and how "race, gender, and power conflicts in our society." "56 After one student complained, the college refused to allow the professor to teach the course. ${ }^{57}$ The Sixth Circuit found in favor of the professor, holding that "[r]easonable school officials should have known that such speech, when it is germane to the classroom subject matter and advances an academic message, is protected by the First Amendment."58 The Sixth Circuit's holding correctly recognized that if protected speech serves a valid and reasonable

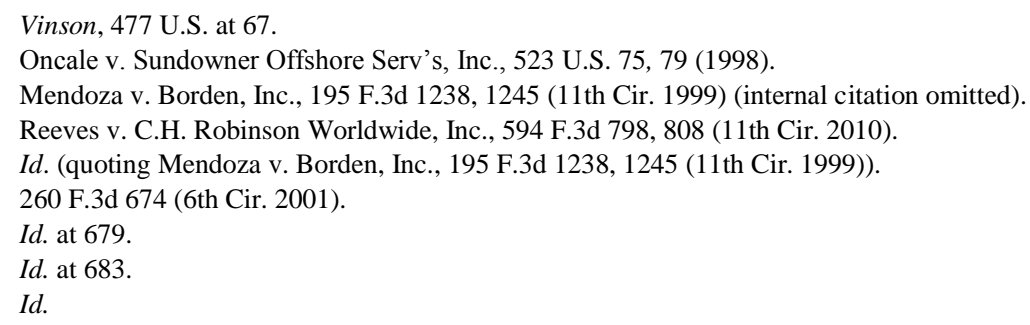


pedagogical purpose in light of a course's subject matter, there is no basis upon which to prohibit its expression.

This is not to say that universities cannot regulate other speech that the Court has deemed unworthy of First Amendment protection, such as obscenity ${ }^{59}$ or in appropriate instances restrict highly offensive speech that would otherwise be protected if not made in a classroom or university context. However, discouraging faculty members from saying, "I think the most qualified person should get the job," prohibiting students from using the words "male" or "female," or penalizing a sorority for "Taco Tuesday" is objectively unreasonable. Doing so does not promote inclusion and certainly does not facilitate the uninhibited exchange of ideas. Rather, it casts a palpable chill over university communities by subtly coercing individuals into silence based on the fear that their expressive conduct, regardless of how innocent, sincere, or protected, can result in severe sanctions.

\section{B. Whether the Speech Would Be Offensive to an Individual of Ordinary Sensibilities}

In the Title VII context, courts have routinely held that the standard for assessing whether "harassing conduct was sufficiently severe or pervasive to alter an employee's terms or conditions of employment includes a subjective and an objective component., ${ }^{160}$ In Harris v. Forklift Systems, Inc., ${ }^{61}$ the Supreme Court stated that "the objective severity of harassment should be judged from the perspective of a reasonable person in the plaintiff's position, considering 'all the circumstances," ${ }_{62}$ including a "careful consideration of the social context in which particular behavior occurs and is experienced by its target." 63 By way of analogy, the tort of intentional infliction of emotional distress requires a plaintiff to demonstrate "the conduct. . .[is] 'so outrageous in character, and so extreme in degree, as to go beyond all possible bounds of decency, and be regarded as atrocious, and utterly intolerable in a civilized community." "64 Indeed, the fact that the "level of atrociousness to which [the behavior] must [rise] is quite high," ${ }_{65}$ reflects the proposition, as evident with the objective reasonableness requirement, that

59 See, e.g., Miller v. California, 413 U.S. 15, 18-20 (1973) (holding that obscenity is not protected by the First Amendment).

60 Mendoza, 195 F.3d at 1246 (citing Harris v. Forklift Systems, Inc., 510 U.S. 17, $21-22$ (1993)).

61510 U.S. 17 (1993).

62 Mendoza, 195 F.3d at 1246 (quoting Oncale, 523 U.S. at 81).

63 Oncale, 523 U.S. at 81.

64 Reynolds v. Ethicon Endo-Surgery, 454 F.3d 868, 873 (8th Cir. 2006) (quoting Harris v. Jefferson Partners, L.P., 653 N.W.2d 496, 500 (S.D. 2002) (quoting ReSTATEMENT (SECOND) OF TORTS $§ 46 \mathrm{cmt}$. d (1965)).

65 Skidmore v. Precision Printing And Packaging. Inc., 188 F.3d 606, 613 (5th Cir. 1999) (alterations in original) (quoting Franklin v. Enserch, Inc., 961 S.W.2d 704, 710 (Tex. App.-Amarillo 1998)). 
not all harms or sensitivities should entitle individuals to a legal remedy or motivate universities to suppress speech.

Courts - and higher education-should embrace this principle in the academic environment. To promote a climate where controversial ideas are confronted, not avoided, and unpopular speech is welcomed, not shunned, universities must accept that there will be opinions, statements, and other forms of expressive activity that they find subjectively offensive. Thus, in order to facilitate meaningful and realistic classroom dialogue, speech or expressive conduct should not be regulated unless it is objectively offensive to individuals of average sensibilities. For example, it may be uncomfortable to discuss rape in a criminal justice course, and it may be disturbing to see images of the Ku Klux Klan in a multiculturalism course. That fact alone, of course, does not make those images less real or history less accurate. Furthermore, the point of discussing rape or showing images of the $\mathrm{Ku}$ Klux Klan is not to cause distress, but to spark dialogue so that students may learn through "speculation, experiment and creation"66 and "thrive in a world full of words and ideas that they cannot control.",67

\section{Whether the Speech Creates a Hostile Educational Environment}

In the Title VII context, when examining if an employer's conduct created a "hostile work environment," courts consider "the frequency of the discriminatory conduct; its severity; whether it is physically threatening or humiliating, or a mere offensive utterance; and whether it unreasonably interferes with an employee's work performance."68 Moreover, the conduct "must be both objectively offensive, meaning that a reasonable person would find it hostile and abusive, and subjectively offensive, meaning that the victim perceived it to be so." $" 69$

A similar standard should apply to determine if a student or faculty member's expressions create a hostile educational environment. Of course this would not mean that a single statement, if sufficiently severe, could not be the basis for a university sanction or legal sanction. In making this determination, courts should consider, among other things, whether the speech is targeted at specific individuals or groups, has a tendency to explicitly or implicitly discourage particular viewpoints, is relevant to the

66 Bakke, 438 U.S. at 312 (quoting Sweezy, 354 U.S. at 263) (Frankfurter, J., concurring in result) (internal quotation omitted).

67 THE ATLANTIC, supra note 19, available at: http://www.theatlantic.com/magazine/archive/2015/09/the-coddling-of-the-american$\operatorname{mind} / 399356 /$

68 Harris, 510 U.S. at 23 (1993).

69 Harvill v. Westward Commc'ns, 433 F.3d 428, 434 (5th Cir. 2005) (emphasis added) (citing Shepherd v. Comptroller of Pub. Accounts, 168 F.3d 871, 874 (5th Cir.1999)) (citing Harris, 510 U.S. at 21-22). 
subject matter being discussed, and is delivered in a professional manner. The Table below provides a few examples of the types of offensive speech that courts would likely permit and prohibit under this standard. ${ }^{70}$

\begin{tabular}{|c|c|c|}
\hline STANDARD & PERMITTED SPEECH & $\begin{array}{l}\text { PROHIBITED } \\
\text { SPEECH }\end{array}$ \\
\hline \multirow[t]{6}{*}{$\begin{array}{l}\text { The speech at issue } \\
\text { must be subjectively } \\
\text { and objectively } \\
\text { unwelcome, offensive } \\
\text { to a person of } \\
\text { reasonable } \\
\text { sensibilities, and } \\
\text { create a hostile } \\
\text { educational } \\
\text { environment }\end{array}$} & $\begin{array}{l}\text { "I think gay } \\
\text { marriage is a sin" }\end{array}$ & $\begin{array}{l}\text { "Homosexuals are } \\
\text { evil" } \\
\text { "God hates fags" }\end{array}$ \\
\hline & $\begin{array}{l}\text { "I think affirmative } \\
\text { action gives jobs to } \\
\text { unqualified people." }\end{array}$ & $\begin{array}{l}\text { "Minorities need } \\
\text { affirmative action } \\
\text { because they are } \\
\text { inferior human beings." }\end{array}$ \\
\hline & $\begin{array}{l}\text { "Can we just call } \\
\text { St. Patrick's day the } \\
\text { white people's } \\
\text { kwanzaa that it is." } 71\end{array}$ & $\begin{array}{l}\text { "We should lynch } \\
\text { all white people." }\end{array}$ \\
\hline & $\begin{array}{l}\text { "White people have } \\
\text { benefited from a long } \\
\text { history of } \\
\text { discrimination and } \\
\text { need a history lesson in } \\
\text { diversity." }\end{array}$ & $\begin{array}{l}\text { "All white people } \\
\text { are racist pigs." }\end{array}$ \\
\hline & $\begin{array}{c}\text { "People from } \\
\text { conservative } \\
\text { backgrounds are less } \\
\text { informed than others." }\end{array}$ & $\begin{array}{l}\text { "People from } \\
\text { conservative } \\
\text { backgrounds are stupid } \\
\text { rednecks." }\end{array}$ \\
\hline & $\begin{array}{l}\text { "I think some } \\
\text { women who are raped } \\
\text { send a message that } \\
\text { they want to have sex." }\end{array}$ & $\begin{array}{c}\text { "If a woman asks } \\
\text { for it, she gets what she } \\
\text { deserves." }\end{array}$ \\
\hline
\end{tabular}

70 The statements in the "permitted" speech column should not be interpreted to suggest the author's approval of them.

71 Joan Venocci, "BU Professor Teaches a Lesson in Offensive Speech,” (July 7, 2015), available at: https:/www.bostonglobe.com/opinion/2015/07/06/less-offensivespeech/VzTnGVA4XCNRXFZDXJgXrN/story.html. 


\begin{tabular}{|c|c|c|}
\hline & $\begin{array}{c}\text { Constructively } \\
\text { criticizing students for } \\
\text { substandard } \\
\text { performance }\end{array}$ & $\begin{array}{c}\text { Calling students } \\
\text { "dunderheads and rat- } \\
\text { like" on social media }^{72}\end{array}$ \\
\hline
\end{tabular}

\section{CONCLUSION}

To obtain a meaningful educational experience and achieve the benefits of a diverse student body, students should confront beliefs they find abhorrent and discuss topics that bring discomfort. As it stands now, universities are transforming classrooms and campuses into sanctuaries for the oversensitive and shelters for the easily-offended. In so doing, higher education is embracing a new, and bizarre, form of homogeneity that subtly coerces faculty members and students into restricting, not expressing, their views, and creating a climate that favors less, not more, expressive conduct. This approach undermines First Amendment values and further divorces higher education from the real world.

The purpose of attending college or graduate school is not merely to acquire knowledge or develop expertise in a chosen field. Students must learn how to interact with people, how to cope with distasteful behavior, and how to learn and respond to adversity. When universities avoid rather than acknowledge the world in which we live, they implicitly cultivate a mindset that views diversity as less, not more, desirable, and that shuns, rather than embraces, a true marketplace of ideas where all viewpoints are welcomed. In a society that values democracy, autonomy, and individuality, nothing is more poisonous or antithetical to the pursuit of knowledge.

\footnotetext{
${ }^{72}$ See, e.g., Munroe v. Central Bucks School Dist., No. 14-3509, 2015 WL 5167011 at *2-3 (September $4,2015)$ (upholding the dismissal of a teacher who made harsh comments about her students on a social media website).
} 